Agroradix Vol. 3 No.1 Desember (2019)

ISSN : 2621-0665

\title{
KAJIAN PENGARUH JUMLAH BIBIT PER LUBANG DAN JARAK TANAM TERHADAP PERTUMBUHAN DAN PRODUKSI PADI (Oryza sativa L.)
}

\author{
Ana Amiroh, Annisa Ullatifah Nazam, dan Suharso \\ Fakultas Pertanian Universitas Islam Darul ‘Ulum Lamongan Jawa Timur \\ Korespondensi : Anaamiroh@unisda.ac.id
}

\begin{abstract}
ABSTRAK
Tanaman padi (Oryza sativa L.) adalah tanaman pokok bagi warga negara Indonesia dimana tanaman ini merupakan tanaman pangan sehari-hari, oleh karena itu kebutuhan padi setiap tahunya meningkat. Di Indonesia kebutuhan tanaman padi semakin melonjak seiring dengan bertambah banyaknya jumlah penduduk. Menurut Anonimous, (2014). Penelitian ini dilaksanakan di desa Botoputih Kecamatan Tikung Kabupaten Lamongan, mulai bulan April sampai dengan bulan juni 2019. Penelitian ini menggunakan metode Rancangan Acak Kelompok (RAK) Faktorial dengan 2 faktor dan setiap faktor terdiri dari 3 level yaitu: faktor pertama yaitu banyak bibit per lubang yang terdiri dari 3 level yaitu 1 bibit/lubang, 2 bibit/lubang, dan 3 bibit/lubang tanaman. Faktor yang kedua yaitu: jarak tanam dengan 3 level yaitu, $20 \times 20 \mathrm{~cm}, 20 \times 25 \mathrm{~cm}$, dan $20 \times 30 \mathrm{~cm}$. penelitian ini dilakukan bertujuan untuk mengetahui kajian pengaruh jumlah bibit per lubang dan jarak tanam terhadap pertumbuhan tanaman padi (Oryza sativa L.). hasil penelitian menunjukan bahwa terjadi interaksi antara jumlah bibit per lubang dan jarak tanam terhadap semua parameter perlakuan. Perlakuan ini menggunakan 1 bibit/lubang dengan jarak tanam $20 \times 30 \mathrm{~cm}$.
\end{abstract}

Kata Kunci : Jumlah bibit, Jarak Tanam, Tanaman Padi.

\begin{abstract}
ABSTRACK
Rice plants (Oryza sativa L.) are staple plants for Indonesian citizens where these plants are daily food crops, therefore the need for rice increases every yearln Indonesia, the need for rice is increasing rapidly as the population increases. According to Anonimous, (2014). This research was carried out in Botoputih village, Tikung Subdistrict, Lamongan Regency, from April to June 2019. This study uses Factorial Randomized Block Design (RBD) method with 2 factors and each factor consists of 3 levels, namely: the first factor is a lot of seeds per hole consisting of 3 levels, namely 1 seed / hole, 2 seeds / holes, and 3 seeds / hole plants. The second factor is: spacing with 3 levels namely, $20 \times 20 \mathrm{~cm}, 20 \times 25 \mathrm{~cm}$, and $20 \times 30 \mathrm{~cm}$. This study was conducted to determine the study of the effect of the number of seeds per hole and the spacing on the growth of rice plants (Oryza sativa L.). the results of the study showed that there was an interaction between the number of seeds per hole and the spacing of all treatment parameters. This treatment uses 1 seed / hole with a spacing of $20 \times 30 \mathrm{~cm}$.
\end{abstract}

Keywords : Number of seed, Rice, Planting distance. 
Agroradix Vol. 3 No.1 Desember (2019)

ISSN : 2621-0665

\section{PENDAHULUAN}

Tanaman padi merupakan tanaman pokok bagi warga negara Indonesia dimana tanaman ini merupakan tanaman pangan seharihari, oleh karena itu kebutuhan padi terus bertambah besar seiring dengan meningkatnya jumlah penduduk. Di Indonesia kebutuhan tanaman padi terus meningkat seiring dengan bertambahnya jumlah penduduk. Menurut Anonimous, (2014).

Selain itu sistem budidaya pertanian mengalami banyak penurunan baik dalam kualitas maupun efisiensi. Penurunan ini sendiri banyak diakibatkan oleh lahan pertanian yang digunakan untuk kebutuhan non pertanian. Banyak juga dari para petani belum bisa menjalankan lahan yang sempit dengan pola penanaman padi yang baik. Seperti halnya penggunaan bibit yang begitu banyak dan jarak tanam yang kurang di atur.

Upaya lain yang harus dilakukan untuk tetap mempertahankan produksi padi yaitu dengan mengoptimalkan jarak tanam dan jumlah bibit per lubang tanaman padi yang nantinya akan sangat berpengaruh terhadap pertumbuhan dan produksi padi. Pengaturan jarak tanam ini sendiri dapat menghindari dari terjadinya tumpang tindih antar tajuk tanaman, yang nantinya akan memberikan ruang bagi perkembangan akar dan tajuk pada tanaman serta meningkatkan ketepatan penggunaan benih, jumlah bibit yang di tanam oleh petani biasanya 1-2 bibit/lubang tanaman .

Oleh sebab itu upaya pengoptimalan penelitian mengenai jarak tanam dan jumlah bibit pada padi masih sangat penting dilakukan, sehingga dapat mendukung pertumbuhan dan perkembangan tanaman serta mendapatkan produksi yang semakin meningkat. Jumlah bibit per lubang tanaman yang semakin sedikit akan memberikan cela pada tanaman untuk memperdalam perakaran serta perlakuan jarak tanam akan memberikan kesempatan tanaman untuk tumbuh dengan baik tanpa mengalami banyaknya kompetisi dalam hal mengambil air, unsur hara, dan cahaya matahari.

\section{BAHAN DAN METODE}

\section{Tempat dan Waktu}

Penelitian ini dilakukan dilahan pertanian di Desa Botoputih Kecamatan Tikung Kabupaten Lamongan. Dengan ketinggian tempat pada lokasi penelitian yaitu $6 \mathrm{mdpl}$. Penelitian ini dilaksanakan pada bulan April sampai dengan juni 2019.

\section{Bahan dan Alat}

Pada penelitian ini bahan dan alat yang digunakan yaitu, benih tanaman padi Trisakti, pupuk Petroganik $500 \mathrm{~kg}$, PHONSKA 300 kg, Urea $200 \mathrm{~kg}$. sedangkan alat yang digunakan adalah cangkul, tugal, ajir, alat pengukur, meteran, timbangan, papan nama, dan alat-alat tulis lainnya.

\section{Metode Penelitian}

Penelitian ini dilakukan dengan menggunakan Rancangn Acak Kelompok (RAK) Faktorial, faktor yng di teliti adalah jarak tanam dan jumlah bibit per lubang dengan 3 level, jarak tanam terdiri dari J1: $20 \times 20 \mathrm{~cm}, \mathrm{~J} 2$ : 
Agroradix Vol. 3 No.1 Desember (2019)

ISSN : 2621-0665

$20 \times 25 \mathrm{~cm}, \mathrm{~J} 3: 20 \times 30 \mathrm{~cm}$ dan jumlah bibit terdiri dari B1 : 1 bibit/lubang, B2 : 2 bibit/lubang, B3 : 3 bibit/lubang. Dari kedua faktor tersebut diperoleh 9 kombinasi perlakuan dan di ulang sebanyak 3 kali sehingga untuk petakan percobaan sebanyak 27 petak percobaan.

\section{PELAKSANAAN PENELITIAN}

\section{Persiapan Lahan}

Persiapan pengolahan lahandi awali dengan pembersihan gulma pada lahan yang akan digunakan untuk melakukan penelitian. Pengolahan lahan menggunakan teraktor dan juga cangkul, dilakukan sebanyak dua kali. Pengolahan pertama bertujuan untuk membalik tanah agar tanah menjadi gembur dan juga mikroorganisme yang bersifat pathogen terkena cahaya matahari dan setelah itu mati. Pengolahan kedua dilakukan supaya tanah menjadi macak-macak sehingga memudahkan dalam penanaman. Setelah di lakukan pengolahan tanah olahan di buat petakan-petakan sesuai dengan perlakuan, ukuran masingmasing petak yaitu $2 \times 2$ meter dan diantara petakan dibuatkan saluran air sekaligus sebagai pembatas antar petakan.

\section{Persemaian}

Benih padi yang digunakan adalah benih varietas Trisakti, dengan kebutuhan benih padi berkisar 3.000-4.000 g/ha. Sebelum melakukan penananam benih padi direndam selama 24 jam tujuannya untuk mengetahui mana benih yang bernas dan mana benih yang hampa, setelah di rendam benih siap untuk di tanam di bedengan persemaian, setelah itu benih yang di semai di tutup dengan naungan yang berfungsi untuk benih agar tidak terkena sinar matahari dan terhindar dari sebaran hama yang ada dilapangan.

\section{Penanaman}

Penanaman dilakukan dengan bantuan manusia yaitu kondisi lahan dalam keadaan tidak tergenang. Penanaman dilakukan pada saat persemaian umur 20 Hst secara serempak dengan jumlah bibit dan jarak tanam tiap perlakuan berbeda.

\section{Pemupukan}

Pengaplikasian pupuk dilakukan dengan cara ditebar secara merata pada petakan. Pada sat pemberian pupuk, air disawah dikeringkan hingga dalam kondisi macak-macak. Pemupukan sendiri dilakuakan mulai 7 Hst dengan jarak 14 hari.

Pupuk yang digunakan sebagai pupuk dasar yaitu dengan dosis $500 \mathrm{~kg}$ Petroganik, 300 kg PHONSKA, dan 200 kg Urea per hektar perlakuan.

\section{Penyulaman}

Penyulaman dilakukan dengan mengganti tanaman yang tidak bisa tumbuh dengan baik ataupun mati yang dilakukan ketika umur $7 \mathrm{Hst}$. Dengan tujuan agar pertumbuhan tanaman menjadi seragam. Tanaman yang digunakan adalah bibit cadangan dari sisa persemaian yang varietasnya sama.

\section{Pengairan}

Pemberian air pada padi ketika saat tanam sampai 3 hari setelah tanam tanah pada kondisi air yang macakmacak, ketika 4 hari setelah tanam sampai dengan 10 hari setelah tanam kondisi air setinggi 2 sampai $5 \mathrm{~cm}$, pada 11 hari setelah tanam sampai menjelang berbunga air dibiarkan tidak 
Agroradix Vol. 3 No.1 Desember (2019)

ISSN : 2621-0665

digenangi atau mengering sendiri selama 5 sampai 6 hari, setelah mengering air diberikan lagi setinggi 5 $\mathrm{cm}$ setelah itu dibiarkan mengering dengan sendirinya lagi dan setelah itu fase berbunga sampai 10 hari sebelum panen air diberikan terus menerus setinggi $5 \mathrm{~cm}$, kemudian pada umur 10 hari sebelum panen sampai panen petakan dikeringkan.

\section{Penyiangan}

Penyiangan dilakukan secara manual dengan membubut gulma yang ada disekitar tanaman padi. Penyiangan dimulai ketika tanaman padi berumur 10 Hst dengan interval 10 hari namun jika dalam seminggu gulma sudah terlihat maka dapat dilakukan penyiangan kembali.

\section{Pengendalian Hama dan Penyakit}

Pengendalian hama dan penyakit ini dilakukan ketika tanaman mulai terjadi gejala serangan hama dan penyakit. Yaitu menggunakan pengendalian hama penyakit terpadu (PHT).

\section{Pemanenan}

Pemanenan dilakukan ketika gabah seluruhnya sudah masak 90\% dari gabah yang berwarna hijau sammpai dengan kuning, sedangkan batang sudah berwarna kuning kecoklatan serta umur panen sudah mencapai 70 sampai dengan 75 hari.

\section{Pengeringan}

Pengeringan ini sendiri dilakukan secara alami, yaitu dengan penjemuran gabah dengan sinar matahari yang dihamparkan di atas lantai semen yang berlapiskan terpal.

\section{Pengamatan dan Pengolahan Data}

Indikator pertumbuhan dan produksi yang diamati yaitu : tinggi tanaman, jumlah anakan, jumlah anakan produktif tanaman padi, berat basah gabah per sampel, berat kering gabah per sampel, berat basah gabah per hektar, berat kering gabah per hektar, bobot $1.000 \mathrm{biji}$

\section{HASIL DAN PEMBAHASAN}

\section{Tinggi Tanaman}

Hasil analisis ragam menunjukan bahwa terjadi interaksi antara perlakuan jarak tanam dan jumlah bibit per lubang terhadap parameter tinggi tanaman padi. Pada umur 14 hst, 21 hst, 35 hst, dan 49 hst.

Tabel 1. Rata-rata tinggi tanaman (cm) pada pengamatan umur 14, 21, 35 dan 49hst

\begin{tabular}{lcccc}
\hline \multirow{2}{*}{ Perlakuan } & \multicolumn{4}{c}{ Rata rata tinggi tanaman (cm) pada umur } \\
\cline { 2 - 5 } & $14 \mathrm{HST}$ & $21 \mathrm{HST}$ & $35 \mathrm{HST}$ & $49 \mathrm{HST}$ \\
\hline J1B1 & $22.07 \mathrm{~cd}$ & $46.93 \mathrm{~cd}$ & $60.33 \mathrm{~cd}$ & $88.93 \mathrm{~cd}$ \\
J1B2 & $21.87 \mathrm{~cd}$ & $46.87 \mathrm{~cd}$ & $60.20 \mathrm{~cd}$ & $88.13 \mathrm{~d}$ \\
J1B3 & $22.00 \mathrm{~d}$ & $45.87 \mathrm{~d}$ & $59.00 \mathrm{~d}$ & $88.07 \mathrm{~d}$ \\
J2B1 & $22.73 \mathrm{bc}$ & $48.13 \mathrm{~b}$ & $61.13 \mathrm{bc}$ & $89.87 \mathrm{~cd}$ \\
J2B2 & $22.40 \mathrm{~cd}$ & $47.93 \mathrm{bc}$ & $60.93 \mathrm{bc}$ & $89.73 \mathrm{~cd}$ \\
J2B3 & $22.33 \mathrm{~cd}$ & $47.60 \mathrm{bc}$ & $60.80 \mathrm{bc}$ & $89.67 \mathrm{~cd}$ \\
J3B1 & $25.33 \mathrm{a}$ & $50.67 \mathrm{a}$ & $65.00 \mathrm{a}$ & $95.73 \mathrm{a}$ \\
J3B2 & $24.60 \mathrm{a}$ & $48.33 \mathrm{~b}$ & $62.13 \mathrm{~b}$ & $92.53 \mathrm{~b}$ \\
J3B3 & $23.27 \mathrm{~b}$ & $48.27 \mathrm{~b}$ & $61.53 \mathrm{bc}$ & $90.20 \mathrm{c}$ \\
\hline \multicolumn{1}{c}{ BNT 5 \% } & 0.85 & 1.17 & 1.41 & 2.01 \\
\hline
\end{tabular}

Keterangan : angka-angka yang diikuti oleh huruf yang sama dalam kolom yang sama tidak berbeda nyata dengan uji BNT $5 \%$ 
Agroradix Vol. 3 No.1 Desember (2019)

ISSN : 2621-0665

Pada table 1 dapat dilihat bahwasnnya kecenderungan semakin lebar jarak tanam yang digunakan maka akan semakin tinggi juga tanaman padi yang di amati dan pertumbuhan tinggi tanaman padi akan semakin cepat dikarenakan tanaman dapat bersaing mendapatkan sinar matahari yang lebih banyak. Begitu pula sebaliknya apabila perlakuan jarak tanam semakin sempit serta perlakuan jumlah bibit yang banyak maka pertumbuhan tanaman padi akan semakin melambat. Pengamatan tinggi tanaman ini sendiri dilakukan pada fase pertumbuhan vegetatif, dimana tajuk tanaman pada padi belum terjadi kompetisi cahaya, unsur hara dan juga air. Guritno dan Sitompul (1995). Menyatakan salah satu cara untuk mendapatkan pertumbuhan yang baik adalah dengan mengatur jarak tanam yang lebih lebar, karena persaingan dalam memperoleh unsur hara, air, dan sinar matahari diantara tanaman menjadi lebih rendah.

\section{Jumlah Anakan}

Hasil analisis ragam menunjukan bahwa terjadi interaksi pada perlakuan jarak tanam dan jumlah bibit pada parameter jumlah nakan tanaman padi. Pada umur pengamatan 14 hst, 21 hst, 35 hst, dan 49 hst.

Tabel 2. Rata-rata jumlah anakan pada tanaman padi umur 14, 21, 35 dan 49 hst.

\begin{tabular}{lllll}
\hline \multirow{2}{*}{ Perlakuan } & \multicolumn{4}{l}{ Rata rata jumlah anakan tanaman padi pada umur } \\
\cline { 2 - 5 } & \multicolumn{1}{c}{ 7 HST } & 21 HST & $35 \mathrm{HST}$ & $49 \mathrm{HST}$ \\
\hline J1B1 & $2.87 \mathrm{~d}$ & $18.53 \mathrm{de}$ & $22.93 \mathrm{~d}$ & $31.40 \mathrm{de}$ \\
J1B2 & $3.33 \mathrm{c}$ & $18.27 \mathrm{ef}$ & $22.80 \mathrm{de}$ & $30.80 \mathrm{ef}$ \\
J1B3 & $4.13 \mathrm{~b}$ & $17.40 \mathrm{f}$ & $21.67 \mathrm{e}$ & $29.47 \mathrm{f}$ \\
J2B1 & $2.87 \mathrm{~d}$ & $19.07 \mathrm{c}$ & $24.13 \mathrm{bcd}$ & $32.60 \mathrm{bcd}$ \\
J2B2 & $3.33 \mathrm{c}$ & $18.87 \mathrm{~cd}$ & $23.93 \mathrm{bcd}$ & $32.40 \mathrm{~cd}$ \\
J2B3 & $4.67 \mathrm{a}$ & $18.80 \mathrm{~cd}$ & $23.13 \mathrm{~cd}$ & $32.13 \mathrm{cde}$ \\
J3B1 & $3.00 \mathrm{~d}$ & $20.00 \mathrm{a}$ & $28.53 \mathrm{a}$ & $37.27 \mathrm{a}$ \\
J3B2 & $3.87 \mathrm{~b}$ & $19.53 \mathrm{~b}$ & $25.13 \mathrm{~b}$ & $34.00 \mathrm{~b}$ \\
J3B3 & $4.80 \mathrm{a}$ & $19.20 \mathrm{bc}$ & $24.53 \mathrm{bc}$ & $33.13 \mathrm{bc}$ \\
\hline BNT 5 \% & 0.32 & 0.42 & 1.40 & 1.42 \\
\hline
\end{tabular}

Keterangan : angka-angka yang diikuti oleh huruf yang sama dalam kolom yang sama tidak berbeda nyata dengan uji BNT $5 \%$

Pada Tabel 2 menunjukan bahwa penggunaan jumlah bibit 1/lubang tanaman dan jarak tanam $20 x$ $30 \mathrm{~cm}$ menghasilkan rata-rata jumlah anakan paling banyak yaitu 37,27 batang pada tanaman padi karena semakin lebar jarak tanam dan semakin sedikit pula jumlah anakan yang digunakan maka akan menghasilkan anakan dengan jumlah yang banyak karena tidak terdapat kompetisi perebutan cahaya matahari, unsur hara, dan juga air. Jumlah anakan akan maksimal apabila tanaman memiliki sifat genetik yang baik serta didukung oleh keadaan lingkungan yang menguntungkan yaitu sesuai dengan pertumbuhan dan perkembangan tanaman (Husna, 2010). Anakan sendiri adalah tanaman yang terdiri dari satu batang, akar dan daun-daun serta dapat juga menghasilkan bunga. Anakan pada padi juga berproduksi menghasilkan 
Agroradix Vol. 3 No.1 Desember (2019)

ISSN : 2621-0665

malai tetapi juga bisa tidak antara jarak tanam dan jumlah bibit per memproduksi malai. lubang terhadap parameter jumlah

Jumlah Anakan Produktif (Tanaman) anakan produktif tanaman padi.

Hasil analisis ragam

menunjukan bahwa terjadi interaksi

Tabel 3. Jumlah anakan produktif (Tanaman) padi

\begin{tabular}{|c|c|}
\hline Perlakuan & Jumlah ankan produktif (Tanaman) padi \\
\hline J1B1 & $26.17 \mathrm{de}$ \\
\hline J1B2 & 25.67 ef \\
\hline J1B3 & $24.56 f$ \\
\hline J2B1 & $27.17 \mathrm{bcd}$ \\
\hline J2B2 & $27.00 \mathrm{~cd}$ \\
\hline J2B3 & $26.78 \mathrm{cde}$ \\
\hline J3B1 & $31.06 \mathrm{a}$ \\
\hline J3B2 & $28.33 b$ \\
\hline J3B3 & $27.61 b c$ \\
\hline BNT $5 \%$ & 0.18 \\
\hline
\end{tabular}

Keterangan : angka-angka yang diikuti oleh huruf yang sama dalam kolom yang sama berbeda nyata dengan uji BNT $5 \%$

Pada tabel 3 dapat dilihat jumlah anakan produktif meningkat pada perlakuan jarak tanam 20 × 30 dengan jumlah bibit 1 /lubang tanaman, karena semakin tinggi anakan yang dihasilkan maka mampu untuk menghasilkan malai atau bisa disebut juga dengan anakan produktif. Anakan produktif sendiri akan muncul ketika menjelang masuk fase generative atau bisa disebut juga pembentukan malai, sehingga anakan prodiktif disebut juga sebagai jumalah anakan yang menghasilkan malai.

Pada fase generative sendiri anakan yang mendapatkan cukup unsur hara tidaka akan mengalami kendala dalam melakukan proses pengisian bulir. Sedangkan proses pengisian bulir yang sempurna dapat menghasilkan jumlah gabah yang lebih banyak. Oleh karena itu semakin banyak jumlah anakan produktif per satuan luas maka semakin banyak juga jumlah malai per satuan luas. Menurut Wangiyana et al. (2009), jumlah anakan produktif ditentukan oleh jumlah anakan yang tumbuh sebelum fase primordial. Namun ada kemungkinan ada peluang bahwa anakan yang membentuk malai terakhir bisa saja tidak akan menghasilkan malai yang bulirnya dapat terisi penuh.

\section{Berat Gabah Basah Per Sampel}

Hasil analisis ragam menunjukan bahwa terjadi interaksi antara perlakuan jumlah bibit dan jarak tanam terhadap parameter berat basah gabah per sampel tanaman padi. 
Agroradix Vol. 3 No.1 Desember (2019)

ISSN : 2621-0665

Tabel 4. Berat Gabah Basah (g) Per Sampel pada tanaman padi

\begin{tabular}{|c|c|}
\hline Perlakuan & Berat Gabah Basah (g) Per Sampel \\
\hline J1B1 & $224.43 \mathrm{~cd}$ \\
\hline J1B2 & $220.67 \mathrm{de}$ \\
\hline J1B3 & $211.57 \mathrm{f}$ \\
\hline J2B1 & $225.93 \mathrm{bc}$ \\
\hline J2B2 & $225.77 \mathrm{c}$ \\
\hline J2B3 & $224.63 \mathrm{~cd}$ \\
\hline J3B1 & $235.37 \mathrm{a}$ \\
\hline J3B2 & $229.77 \mathrm{~b}$ \\
\hline J3B3 & $228.10 \mathrm{bc}$ \\
\hline BNT $5 \%$ & 4.24 \\
\hline
\end{tabular}

Keterangan : angka-angka yang diikuti oleh huruf yang sama dalam kolom yang sama berbeda nyata dengan uji BNT $5 \%$

Pada Tabel 4 dapat dilihat dari pengamatan bobot basah gabah per sampel tanaman padi bahwa perlakuan jarak tanam 20 × $30 \mathrm{~cm}$ dan jumlah bibit 1/lubang tanaman mendapatkan hasil yang tertinggi, pemgambilan sampel ini sendiri yaitu dengan menimbang gabah yang masih terdapat kadar air di dalamnya. Karena dengan demikian dapat diketahui bahwa kualitas fisik gabah ditentukan oleh kadar air didalam butiran gabah itu sendiri. Hesthiati et al, (2012). Menyatakan, bahwa penggunaan jumlah bibit 1 per lubang tanaman dapat menyebabkan tinggi tanaman, panjang malai, jumlah malai, jumlah bulir, bobot gabah basah, bobot gabah kering yang lebih baik dari penggunaan jumlah bibit lainnya.

\section{Berat Gabah Kering Per Sampel Tanaman Padi}

Hasil analisis ragam menunjukan bahwa perlakuan jarak tanam dan jumlah bibit per lubang pada tanaman padi terjadi interaksi terhadap bobot gabah kering per sampel tanaman padi.

Tabel 5. Berat Gabah Kering (g) per sampel pada tanaman padi

\begin{tabular}{ll}
\hline \multicolumn{1}{c}{ Perlakuan } & Berat Gabah Kering (g) Per Sampel \\
\hline J1B1 & $168.56 \mathrm{de}$ \\
J1B2 & $165.34 \mathrm{ef}$ \\
J1B3 & $158.18 \mathrm{f}$ \\
J2B1 & $175.00 \mathrm{bcd}$ \\
J2B2 & $173.93 \mathrm{~cd}$ \\
J2B3 & $172.50 \mathrm{cde}$ \\
J3B1 & $200.06 \mathrm{a}$ \\
J3B2 & $182.52 \mathrm{~b}$ \\
J3B3 & $177.87 \mathrm{bc}$ \\
\hline BNT 5 \% & 7.62 \\
\hline
\end{tabular}

Keterangan : angka-angka yang diikuti oleh huruf yang sama dalam kolom yang sama berbeda nyata dengan uji BNT $5 \%$ 
Agroradix Vol. 3 No.1 Desember (2019)

ISSN : 2621-0665

Pada Tabel 5, dapat dilihat bahwa perlakuan jarak tanam dan jumlah bibit/lubang tanaman padi terjadi interaksi pada jarak tanam $20 \mathrm{x}$ $30 \mathrm{~cm}$ dan jumlah bibit 1/lubang tanaman. Cara menghitung berat kering ini sendiri yaitu dengan menimbang gabah yang digunakan pada setiap sample dalam keadaan sudah di kurangi kadar air di dalamnya atau dalam keadaan kering. Semakin sedikit jumlah bibit yang digunakan maka hasil gabah kering panen yang dihasilkan akan semakin meningkat (Muyasir, 2012).

Pertumbuhan tanaman yang baik akan menghasilkan tanaman yang maksimal. Disini faktor pertumbuhan pada tanaman yang memiliki peran penting dalam pertumbuhan yaitu, cahaya matahari karena cahaya matahari sangat berperan penting dalam proses fotosointesis selain itu dari fotosintesis tanaman akan menghasilkan fotosintat yang akan menghasilkan produksi tanaman yang baik.

\section{Berat Gabah Basah (t) Per Hektar}

hasil analisis ragam menunjukan bahwa perlakuan jarak tanam dan jumlah bibit terjadi interaksi pada parameter berat gabah basah per hektar tanaman padi.

Tabel 6. Berat Gabah Basah (t) Per Hektar pada tanaman padi

\begin{tabular}{lc}
\hline \multicolumn{1}{c}{ Perlakuan } & Rata-rata Berat Gabah Basah $(\mathrm{t})$ Per Hektar \\
\hline J1B1 & $10.32 \mathrm{~cd}$ \\
J1B2 & $10.27 \mathrm{~cd}$ \\
J1B3 & $10.23 \mathrm{e}$ \\
J2B1 & $10.42 \mathrm{bcd}$ \\
J2B2 & $10.40 \mathrm{bcd}$ \\
J2B3 & $10.40 \mathrm{bcd}$ \\
J3B1 & $10.84 \mathrm{a}$ \\
J3B2 & $10.53 \mathrm{bcd}$ \\
J3B3 & $10.42 \mathrm{bc}$ \\
\hline BNT 5 \% & 0.18 \\
\hline Keterangan : angka-angka yang diikuti oleh huruf yang sama dalam kolom yang sama \\
\multicolumn{2}{c}{ berbeda nyata dengan uji BNT 5\% } \\
bahwa penggunaan bibit 1/lubang & ada persaingan terlalu banyak menurut \\
tanaman memperlihatkan hasil gabah & Yasin M. (2012).
\end{tabular}

basah tertinggi yaitu 10,84 ton/ha.

Dikarenakan penggunaan bibit yang semakin sedikit mempengaruhi hasil gabah basah per hektar pada tanaman padi. Karena berbanding lurus dengan jumlah anakan. Dalam penelitian yaitu penggunaan 1 bibit/lubang akan memperkuat perakaran karena tidak

\section{Berat Gabah Kering Per Hektar}

Hasil analisis ragam menunjukan bahwa terdapat interaksi antara perlakuan jarak tanam dan jumlah bibit terhadap parameter berat kering per hektar pada tanaman padi. 
Agroradix Vol. 3 No.1 Desember (2019)

ISSN : 2621-0665

Tabel 7. Berat Gabah Kering (t) Per Hektar pada tanaman padi

\begin{tabular}{lc}
\hline \multicolumn{1}{c}{ Perlakuan } & Berat Gabah Kering $(\mathrm{t})$ Per Hektar \\
\hline J1B1 & $9.18 \mathrm{~cd}$ \\
J1B2 & $9.14 \mathrm{~cd}$ \\
J1B3 & $9.11 \mathrm{~d}$ \\
J2B1 & $9.27 \mathrm{bc}$ \\
J2B2 & $9.26 \mathrm{bcd}$ \\
J2B3 & $9.26 \mathrm{bcd}$ \\
J3B1 & $9.65 \mathrm{a}$ \\
J3B2 & $9.38 \mathrm{~b}$ \\
J3B3 & $9.28 \mathrm{bc}$ \\
\hline BNT 5 \% & 0.16 \\
\hline
\end{tabular}

Keterangan : angka-angka yang diikuti oleh huruf yang sama dalam kolom yang sama berbeda nyata dengan uji BNT $5 \%$

Pada Tabel 7, hasil gabah merupakan salah satu parameter yang sangat penting dalam menentukan tingkat produktifitas suatu tanaman. Karena semakin tinggi hasil panen yang diperoleh maka semakin tinggi pula produktifitas yang di peroleh. Hal ini disebabkan dari efek jarak tanam dan jumlah bibit/lubang, dimana tanaman cukup mendapatkan suplai nutrisi, air dan juga sinar matahari. Dengan demikian akan mengakibatkan proses fotosintesis berlangsung optimal. Menurut Muyasir (2012). Yang berujar bahwa jarak tanam berdampak nyata terhadap hasil tegel yang terbaik pada jarak tanam $20 \times 30 \mathrm{~cm}$. Hal ini dikarenakan efek dari dampak sistem jarak tanam dan jumlah bibit/lubang tanaman, disebabkan oleh tanaman cukup mendapat nutrisi, air dan juga sinar matahari.

\section{Berat 1.000 biji}

Hasil analisis ragam menunjukan bahwa terdapat interaksi antara perlakuan jarak tanam dan jumlah bibit pada parameter berat 1.000 biji tanaman padi.

Tabel 8. Rata-rata berat 1.000 biji (g) pada tanaman padi

\begin{tabular}{ll}
\hline Perlakuan & Rata rata berat $1.000 \mathrm{biji}(\mathrm{g})$ \\
\hline J1B1 & $27.40 \mathrm{~cd}$ \\
J1B2 & $27.33 \mathrm{~cd}$ \\
J1B3 & $27.10 \mathrm{~d}$ \\
J2B1 & $27.60 \mathrm{bc}$ \\
J2B2 & $27.53 \mathrm{bc}$ \\
J2B3 & $27.47 \mathrm{~cd}$ \\
J3B1 & $28.53 \mathrm{a}$ \\
J3B2 & $27.87 \mathrm{~b}$ \\
J3B3 & $27.67 \mathrm{bc}$ \\
\hline BNT 5 \% & 0.37 \\
\hline
\end{tabular}

Keterangan : angka-angka yang diikuti oleh huruf yang sama dalam kolom yang sama berbeda nyata dengan uji BNT $5 \%$

Dari Tabel 8, menunjukan 1000 butir gabah tanaman padi semakin semakin lebar jarak tanam maka bobot besar. Nilai paling besar bobot 1000 
Agroradix Vol. 3 No.1 Desember (2019)

ISSN : 2621-0665

butir gabah terdapat pada jarak tanam $20 \times 30 \mathrm{~cm}$. Dan untuk jumlah bibit perlubang semakin sedikit maka nilai bobot 1000 butir gabah tinggi, begitupula sebaliknya semakin banyak jumlah bibit/lubang semakin rendah bobot 1000 butir gabah. Bertambahnya jumlah bibit per tanaman berpotensi meningkatkan persaingan baik antara tanaman satu rumpun dengan rumpun lainnya terhadap cahaya, ruang, dan unsur hara sehingga sangat berpengaruh terhadap pertumbuhan dan produksi. Menurut Syaiful Syatrianty A; Sennang N.S. dan Yasin M. (2012).

\section{KESIMPULAN DAN SARAN}

\section{Kesimpulan}

Dari hasil penelitian yang dilakukan dapat dilihat bahwa :

Perlakuan jarak tanam $20 \times 30$ $\mathrm{cm}$ dan jumlah bibit 1/lubang tanaman terjadi interaksi terhadap semua parameter perlakuan, sehingga menghasilkan produksi gabah basah per hektar mencapai 10,84 t/ha dan produksi gabah kering per hektar mencapai 9,65 t/ha.

\section{Saran}

Dari hasil penelitian yang telah dilakukan, penulis menyarankan bagi pembaca agar menggunakan perlakuan jarak tanam $20 \times 30 \mathrm{~cm}$ dan jumlah bibit 1 /lubang tanaman padi.

\section{DAFTAR PUSTAKA}

BPS. 2014. Produksi Padi Pada Tahun 2014(Angka sementara) Diperkirakan Turun 0,63 Persen. http://bps.go.id.Diakses tanggal 20 Maret 2015.
Hesthiati dan Rawiniati. 2012 Produksi Padi (Oryza sativa L.) Pada Jarak Tanam dan Jumlah Bibit Per Lubang Tanama yang Berbeda yang Ditanam Secara Organik pada System Of Rice Intensification (Sri).

Husna, Y. 2010. Pengaruh Penggunaan Jarak Tanam Terhadap Pertumbuhan dab Produksi Padi Sawah (Oryza sativa L.). Varietas Batang Piaman dengan Metode SRI (System of Rice Intensification). Jurnal. Jurusan Agroteknologi. Fakultas Pertanian, Universitas Riau. Vol(9): 2-7

Muyassir. 2012. Efek Jarak Tanam, Umur dan Jumlah Bibit Terhadap Hasil Padi Sawah (Oryza sativa L.). J. Manajemen Sumberdaya Lahan. 01(02): 207-212.

Sitompul, S.M dan B. Guritno. 1995. Analisis Pertumbuhan Tanaman. Gadjah Mada University Press. Yogyakarta.

Syaiful Syatrianty A; Sennang N. S. Dan Yasin M. 2012. Pertumbuhan dan Produksi Padi Hibrida Pada Pemberian Pupuk Hayati dan Jumlah Bibit Per Lubang Tanam, Jurnal Agrivor 11(2): 202-213.

Wangiyana, W., Z. Laiwan dan Sanisah. 2009. Pertumbuhan dan Hasil Tanaman Padi Var. Ciherang Dengan Teknik Budidaya "SRI (System OF Rice Intensification)" Pada 
Agroradix Vol. 3 No.1 Desember (2019)

ISSN : 2621-0665

Berbagai Umur dan Jumlah

Bibit Per Lubang Tanaman. J

. agro Crop Science. 2(1):70-

78 